\title{
Humanistic Approach in Supervision and Evaluation of Islamic Religious Education
}

\author{
Yanti Nurdiyanti' ${ }^{1}$, Zainal Arifin ${ }^{2}$ ) Wawan Ridwan ${ }^{3}$ Dodo Suhada ${ }^{4}$ Mohamad Erihadiana ${ }^{5}$ \\ 1)STITNU Al Farabi Pangandaran, Indonesia \\ 2)UIN Sunan Kalijaga, Indonesia \\ 3)SMA Plus Ma'ruful Hidayah Garut, Indonesia \\ 4)STAIMA Kota Banjar, Indoensia \\ 5) Universitas Islam Negeri Gunung Djati Bandung, Indonesia \\ email: yantinurdiyanti@stitnualfarabi.ac.id, zainal.arifin@,uin-suka.ac.id, cikajangridwan@gmail.com, \\ 01dodosuhada@gmail.com, erihadiana@uinsgd.ac.id.
}

Received: 25-10-2021

Revised: 21-12-2021

Accepted: 24-12-2021

\section{Article Information \\ Abstract}

Keywords:

Supervision, Evaluation, Humanistic Approach.

Supervision and evaluation of Islamic Religious Education (IRE) teachers are still experiencing obstacles so that supervision is less effective. One of them is caused by the low level of cooperativeness of teachers in the supervision process due to teachers feeling more senior and less communicative. So it needs the right approach so that the monitoring process runs effectively. This study aims to analyze the humanistic approach in the supervision and evaluation of IRE teachers at SMP Pangandaran Regency. The method used is qualitative with a case-study approach. For data collection using interview and documentation techniques. Data analysis using miles and hubarman model. As well as the validity test using the credibility test with the triangulation method. The results showed that the supervision and evaluation by supervisors of IRE teachers in Pangandaran district junior high schools was carried out by: 1) Observing performance through academic supervision 2) Intensive guidance 3) Personal and group coaching 4) Development, direction to improve performance and career development 5 ) The assessment is submitted in the form of an academic supervision report. Supervision with a humanistic approach is carried out by adhering to three principles: 1) Opportunity, providing opportunities for improvement, 2) self evaluation, identifying deficiencies and exploring self-potential so as to improve teacher performance. 3) Upgrading, directing and facilitating teachers to improve competence and understand the development of information and technology.

Kata kunci:

Pengawasan, Evaluasi, Humanistic Approach.

\begin{abstract}
Abstrak
Pengawasan dan evaluasi guru Pendidikan Agama Islam masih mengalami kendala sehingga pengawasan kurang efektif. Salah satunya diakibatkan oleh rendahnya tingkat koopratif guru dalam proses pengawasan yang disebabkan kearena guru merasa lebih senior dan kurang komunikatif. Sehingga perlu pendekatan yang tepat agar proses pengawasan berjalan efektif. Penelitian bertujuan untuk mengalisis pendekatan bumansitik dalam pengawasan dan evaluasi terbadap guru PAI di SMP Kabupaten Pangandaran. Metode yang digunakan yaitu kualitatif dengan pendekatan study kasus. Teknik pengumpulan data dilakukan dengan menggunakan wawancara dan dokumentasi. Analisis data
\end{abstract}


menggunakan model miles and hubarman. Serta uji keabsahan menggunakan uji kredibilitas (credibility) dengan metode trianggulasi. Hasil penelitian menunjukan bahwa pengawasan dan evaluasi oleh pengawas terhadap guru PAI di SMP kabupaten Pangandaran dilakukan dengan:1)Pengamatan kinerja melalui supervisi akademik 2)Bimbingan intensif 3)Pembinaan secara personal maupun kelompok 4) Pengembangan, pengarahan untuk melakukan perbaikan kinerja dan pengembangan karir 5)Penilaian yang disampaikan dalam bentuk laporan supervisi akademik. Pengawasan dengan pendekatan bumanistik dilakukan dengan berpegang pada tiga prinsip: 1) Opportunity, memberi kesempatan untuk melakukan perbaikan, 2) self evalution, melakukan identifikasi terhadap kekurangan serta menggali potensi diri sehingga mampu memperbaiki kinerja guru. 3)Upgrading, Mengarabkan serta memfasilitasi guru agar meningkatkean kompetensi serta memahami perkembangan informasi dan teknologi.

\section{INTRODUCTION}

Management of Supervision and Evaluation is one way to clarify the implementation of the quality standards of Islamic Religious Education (IRE) that have been determined by the Ministry of Religion through the Directorate General of Islamic Education. IRE supervisors in schools are Civil Servant teachers who are appointed in the Functional Supervisory Position, with duties and responsibilities, as well as their authority in supervising the implementation of IRE in schools to formulate policies, carry out coordination, harmonization and synchronization of policies and the implementation of supervisory development. in accordance with what is stated in the Guidelines for the Guidance of Madrasah Supervisors and Islamic Religious Education Supervisors in Schools.

However, in the implementation of supervision carried out by IRE supervisors, there are still many obstacles. Based on the reference to the results of previous research, the supervision carried out by the ministry of religion on IRE teachers, there is a gap in the number of supervisors with the number of teachers under their supervision, the geographical location of the school is quite far and difficult to reach in carrying out direct supervision. Besides that, other factors are less cooperative actions from teachers in the implementation of supervision, and the cause is because teachers feel more senior and less communicative (Maranting, 2020). Therefore, a method through a certain approach is needed to optimize the implementation of supervision.

Factors that affect the work environment are coloring, cleanliness, lighting, air exchange, music, safety and noise. while the influencing work culture factors are: (1) the condition of the physical work environment, such as giving awards, providing welfare, fulfilling facilities and infrastructure. (2) working environment conditions, such as support in carrying out tasks, communication and interaction with peers, parents, school principals and the community (Lutfah et al., 2019).

In a study conducted by Miftahul Ulum, one of the Monitoring Methodologies used a Religious Approach. The results of the study revealed that supervision with a religious approach was carried out in the form of a rational approach, an affective-approach, a habituation approach, and an exemplary approach. Besides that, the Religious Approach in supervision adheres to five principles, namely: working solely for Him, working as a means of communication with Him, a symbol of submission and obedience to Him, that work is done solely because of worship so that wherever and whenever with or without anyone supervising the teacher, he continues to carry out his performance well because he feels that Allah SW'T is always watching (Miftahul Ulum, 2020). 
Based on the information we received from the IRE supervisor at a junior high school in Pangandaran Regency, the results of the supervision findings are that there are still many teachers who experience deficiencies in completing learning administration reports, teacher performance is low so that the right approach method is needed to solve these problems so that they can assist teachers to be able to and want to improve its performance. And what supervisors do in dealing with these problems, supervision is carried out through a humanistic approach considering the various factors that cause problems that occur so that space and opportunities are needed for teachers to improve performance by understanding the situation and condition of the teacher himself.

Implementation of the humanistic approach in education focuses on developing emotional, social, mental, and career skills. The flow of Humanistic Psychology always encourages the improvement of the quality of human beings through appreciation of the positive potentials that exist in every human being. Along with the changes and demands of the times, the educational process is always changing (Rachmahana, 2008).

The research that supports this research is research conducted by the Head of the Department of Education (Supervisor of the Gabus Pati District Education Office) with the research title "Improving Teacher Ability in Scientific Thematic Learning Through Clinical Supervision of Humanistic Approach Implant Techniques for Class IV Teachers Dabin I Gugus Sukarno-Hatta Education Office Gabus District, Pati Regency in IT Senester". The results showed that through the application of clinical supervision using a humanistic approach there was a significant increase in the ability and professionalism of teachers (Kadis, 2015).

The supervision model with a humanistic approach has been tested for its feasibility to improve the professionalism of high school BK teachers in Kubu Raya Regency, because it is expected for supervisors to apply the development of the supervision model as a reference in coaching counseling and guidance teachers. The supervision model developed will certainly assist supervisors in improving the professionalism of BK teachers which have an impact on the progress of education in Kubu Raya Regency, therefore the Kubu Raya Education Office must always provide both moral and material support so that the guidance carried out will have an impact on the progress of education in a sustainable manner (Prakasiwi, A.E, Suarni, K.N, Gading, 2013).

\section{THEORY AND LITERATURE}

According to George R Terry quoted by Badrudin (2013) that the management functions consist of planning, organizing, actuating and controlling. Controlling consists of monitoring and evaluation carried out in the process of ensuring that the planning is carried out in accordance with the objectives and standardization that has been determined to obtain references in carrying out follow-up improvements (Badrudin, 2013).

McCarty EJ, Ricardh D Irwin (in the School of Business) quoted by Zainal Arifin (2020) explains that controlling and evaluation have the same meaning but have several differences, namely: Control is a feedback process to help managers know about: 1) The planning process that is being done and 2) How to plan for the future. While the supervision of how to maintain the predetermined goals are achieved, namely by detecting deviations so that corrective actions need to be taken. While evaluation is a review based on the results of a program in order to obtain certainty of the results achieved (Zainal Arifin, 2020).

Supervision is an effort to make activities and activities carried out able to be realized based on the plans that have been programmed. Therefore, planning as the first function of management 
is carried out and practiced and achieved the goals and objectives that have been determined. In line with that, E. Mulyasa quoted by Miftahul Ulum (2020) also stated that supervision means observation activities so that work is actually carried out in accordance with the provisions (Miftahul Ulum, 2020).

The evaluation standards committee defines evaluation as a systematic and orderly study of the benefits or uses of some objects (Committe, 1981). Stufflebeam in Lababa (2008) suggests that evaluation is "The process of delineating, obtaining and providing useful information for judging decision alternatives" (Stufflebeam dalam Lababa, 2008). Evaluation is a process taken to obtain useful information that can be used in determining the desired alternative in determining the decision to get the best alternative based on the value of relativity, not just a random choice, using rational considerations based on information (Usman, 2009). Evaluation is a process of describing, obtaining and providing useful information in formulating various alternative decisions (Badrudin, 2013). And the best evaluation model is an evaluation model that can evaluate the program according to the program's needs (Adib et al., 2019).

In the Koran, supervision and evaluation is implied in the QS. Al-Hasyr (59) verse 18, Ibn Kathir interprets the sentence "And let everyone pay attention to what he has done for tomorrow (the Hereafter)", namely reckoning everything that you have saved for yourself in the form of righteous deeds as a provision in the future. hereafter when you meet your Lord. The commandment to pay attention to what has been done for tomorrow is understood by Thathaba'i (in The Shihab, 2017), as an order to evaluate the deeds that have been done, is likened to a handyman who has finished his work and is then required to pay attention to it again so that it is perfected if the results are good, and make repairs if there are deficiencies in his work, so that when the time comes for inspection, no deficiencies are found and this item looks perfect(Zainal Arifin, 2020).

\section{Main Duties and Functions of Supervisor}

Referring to the Regulation of the Minister of Religion of the Republic of Indonesia no. 2 of 2012 concerning madrasa supervisors and Islamic religious education supervisors in schools, it is conveyed about the duties, responsibilities and authorities of school supervisors. Supervisors of Islamic Religious Education (IRE) at schools are Civil Servant Teachers who have functional positions as supervisors of Islamic religious education with the duties, responsibilities, and authorities to supervise and ensure the implementation of Islamic Religious Education in quality schools. IRE supervisors at schools are tasked with supervising Islamic Religious Education in schools at the level of Kindergarten, SD/SDLB, SMP/SMPLB, SMA/SMALB and/or SMK. IRE supervisors have the function to carry out: preparation of supervision programs, coaching, guidance and professional development of IRE teachers, monitoring of the implementation of PAI national standards, Delivering the results of the implementation of the supervision program; and complete reporting on the implementation of supervisory duties.

In the Qur'an in Surah QS. Qaaf verse 18, it is implied that the duty of a supervisor is to take corrective actions and carry out evaluations, until teachers and students are able to carry out their duties properly (Gusmadi, 2016).

Based on Ministerial Regulation No. 2 of 2012 Regarding madrasa supervisors and Islamic religious education supervisors in schools, it was stated that IRE supervisors in schools were responsible for improving the quality of planning processes and results of education and learning in schools. Supervisors have the authority to provide input, advice and guidance in the process of 
compiling the implementation and evaluation of IRE learning education, monitoring and evaluating the performance of IRE teachers, providing guidance, and conveying assessment considerations and recommendations for the placement of IRE teachers to the principal and authorized officials.

\section{Humanistic Approach}

The term "humanism" is widely applied to various disciplines, especially in the fields of philosophy, literature, and education. There are several differences in the concept of humanism but basically rooted in the same pillar, namely focusing on human values that focus on efforts to elevate human dignity (Untari, 2016).

There are two most basic assumptions in humanistic theory, namely formative tendencies and self-actualization tendencies. The formative tendency is a tendency in all forms, both organic and inorganic, which leads to the development of simple forms to more complex forms. The tendency to actualize where the tendency of every living thing to grow and develop towards perfection or fulfill self-potential (Jess Feist dan Gregory J. Feist, 2008). Every individual has a creative ability to solve problems.

In Maslow's theory quoted by Rachmana, the hierarchy of human needs consists of: Physical needs which are primary needs such as eating, drinking, sleeping and sex needs; The need for security includes the need for health and the need to avoid disasters; The need to belong and be loved, such as the need to have friends and family, to belong to a group; and esteem needs, such as the need to be valued, respected, and trusted by others. These four categories are called deficiency needs because they depend on other people for their fulfillment (Rachmahana, 2008).

The concept of humans in the Qur'an that humans are actually the children of Adam has been glorified by Allah who is equipped with various facilities to be made the best of creation than all His creatures. This shows that humans are born with the potential to develop better. So, that humans are called insan kamil (perfect human) (Budiyanti et al., 2020). The concept of the perfect and ideal human (Insan Kami) in Islam is a study that is quite attractive and very important for us to know. Insan Kamil is a harmony of two forms in humans, the first form is the existence of perfection in terms of form which includes all the devices that exist in humans. Such perfection is a gift from Allah, as a form of manifestation that comes from the ability to guard oneself from everything that can hurt and harm oneself and also the ability to use it. While the second is the perfection of knowledge. The perfection of this knowledge is based on curiosity to gain knowledge. So that curiosity encourages humans to be able to use and utilize the potential that exists in themselves to study as much as possible (Harahap \& Siregar, 2017).

The concept of humans in the Qur'an Surah Al-Isra (17) verse 70 that humans are the children of Adam have been glorified by Allah who is provided with sustenance from the good and We have preferred them above many creatures that We created with advantages that perfect" (Zainal Arifin, 2020).

\section{Self and Self Actualization}

In the humanistic theory, Carl Rogers stated that personality changes and develops, where there are three constructs that are the important basis in his theory, namely: Organism, Phenomenon Field, and Self. (the article from journalists. Gunadarma entitled Carl Rogers' humanistic theory quoted by Bau Ratu, 2009) (Ratu, 2009) .

Organisms include three important things, namely; 1) Living organisms are organisms which are complete beings with physical and psychological functions and are places for various experiences, as well as self-potential. 2) Subjective Reality of Organisms, which assumes that the 
world is as experienced and observed. While Reality is a perception that is subjective in nature and can shape behavior. 3) Holism An organism that is a unified system, so that changes in one part will have an effect on other parts. Each change has a personal meaning and purpose, namely the purpose of actualizing, maintaining, and developing oneself.

The field of phenomena is the entire experience internally and externally, consciously or unconsciously. The field of this phenomenon is the entire personal experience of a person throughout his life in the world, as well as his subjective perception.

Self, Self is divided into 2 subsystems, namely self-concept and ideal self. Self-concept, namely the incorporation of aspects of one's existence and experience and is realized by the individual (although not always accurate). According to Rogers, self-concept is a consistent inner awareness of experiences related to something that distinguishes himself and others (I and not me) (Schultr, Duane;1991). There are two self-concepts, namely the real self-concept and the ideal selfconcept. In showing the suitability of the two self-concepts, Rogers then gave two more concepts, namely Incongruence and Congruence. Incongruence is a discrepancy between the self that is perceived by actual experience and accompanied by inner conflict and confusion. Meanwhile, Congruence means a situation of self-experience that is carefully expressed in a complete, integral, and true self-concept. The ideal self is a person's ideals of himself. The fact gap will cause imbalance and unhealthy personality.

According to Carl Rogers there are several things that affect Self, namely: Awareness, Maintenance Needs, Self-improvement, positive regard (positive regard) and positive self-regard (positive self-regard) (Ratu, 2009).

Awareness, with the awareness of a person gives the concept of self and the ideal self. There are 3 levels of consciousness. 1) Experiences that are felt subconsciously will be rejected or denied. 2) Experiences that can be symbolically actualized will be directly recognized by the self-structure. 3) Perceived experience in the form of distortion. If the experience felt is not in accordance with the self, then it is reshaped and distorted so that it can be assimilated by the self-concept. Maintenance needs, maintenance of the organismic body and its satisfaction with food, water, air, and security, so that the body tends to want to be static and refuse to develop. Self-improvement, eventhough the body refuses to develop, the self also has the ability to learn and change. Positive regard (positive regard), Once awareness arises, the need to be loved, liked, or accepted by others. Positive self-regard, the development of a need for self-regard as a result of experiences with satisfaction or frustration (Ratu, 2009).

\section{RESEARCH METHODS}

The qualitative research approach according to Creswell (2012) is divided into five types, namely; Phenomological, Grounded Theory, Ethnography, Case Study, Narrative. This mini research uses a case study where the researcher conducts an in-depth exploration of the program, event, process. This research method uses a qualitative method with the type of case study research where the researcher conducts an in-depth exploration of the program, event, process, activity, against one or more people (Creswell, 2012). In this mini research, the researcher explores the implementation of supervision by supervisors for PAI teachers in Pangandaran Regency.

Data collection techniques in this mini research used interview and documentation methods. The interview technique used using semi-structured interviews, namely the interview process is more free than structured interviews, not only preparing interview instruments with alternative 
answers, but the interviewees are given the opportunity to convey their ideas, ideas and opinions so that they find problems more openly (Sugiyono, 2013). The resource persons in this study were PAI supervisors at junior high schools in Pangandaran Regency, namely Ms. Hj Ai Siti Rohmah, MM, one PAI teacher at PNS SMP, Mrs. Yoyom Siti Rohmah, S.Pd.I and one PAI teacher at NonPNS SMP, Mr. Suryana, S.Pd. .I. In digging up the data in this study, in addition to using the interview method, the researcher also uses the documentation method.

Documentation is looking for data about things or variables in the form of notes, transcripts, books, newspapers, websites, magazines, inscriptions, minutes, agendas and so on that have a relationship with the topic under study (Sugiyono, 2013). Document analysis used in this research are; guidebook for the implementation of supervision and development of PAI teachers, instruments for implementing academic supervision and academic supervision reports. Data analysis uses the Miles and Huberman model, namely the process of analyzing data reduction, displaying data, and making conclusions (Sugiyono, 2018). Test the validity of the data using the credibility test which is carried out by the triangulation method.

\section{RESULTS AND DISCUSSION}

Referring to the Guidelines for the Guidance of Madrasah Supervisors and Islamic Religious Education Supervisors in Schools issued by the Ministry of Religion through the Directorate General of Islamic Education Director of Madrasah Education in 2014 School/Madrasah Supervisors are PNS teachers who are appointed to functional positions as supervisors of educational units whose duties, responsibilities, and authority to supervise. The requirements or principles in question are: (1) It has been carefully planned, (2) Has standard operational procedures, (3) Executed by a trustworthy and capable person, (4) Accountable or transparent (5) Efficient in the use of the budget. If this principle is owned by every organization, it will minimize all forms of problems in the field. Efforts to monitor or control maximally by elements in the organization can go through these principles (Noer Rohmah 1, 2019).

Supervisors of educational institutions must have a very important and significant role in improving the professionalism of teachers so as to produce quality education aimed at the education system, the role of these supervisors is none other than specifically as quality control in educational institutions (Sutiah, 2016).

Supervision consists of academic supervision and managerial supervision. Academic supervision aims to assist or foster teachers in improving the quality of the learning process in order to obtain more optimal student learning outcomes. Academic supervision is a supervisory function related to aspects of coaching and developing professional abilities in improving the quality of learning and guidance in schools. In carrying out the function of academic supervision, a supervisor will have roles such as: (a) teacher partners in improving the quality of processes and outcomes of learning and guidance in the target schools; (b) innovators and pioneers in developing learning innovations and guidance in their target schools; (c) education consultant in the target school; (d) counselors for principals, teachers and all school staff; (e) motivator to improve the performance of all school staff (Joko Budi Santoso, 2011).

Efforts in optimizing to achieve the quality of education are carried out by monitoring the duties of teachers carried out by supervisors and principals (Fauzi, 2017). Meanwhile, managerial supervision aims to assist and foster school principals in their efforts to improve the quality of education through optimizing school performance. 
Based on the results of interviews and analysis of documentation to the Supervisor of PAI SMP teachers in Pangandaran Regency. Supervision consists of a program of supervision, implementation of guidance, monitoring of the implementation of the 8 (eight) National Education Standards, assessment, guidance and professional training of teachers, evaluation of the results of the implementation of supervision programs, and implementation of supervisory duties in special areas. Supervision and supervision are carried out every month. The number of IRE teachers who are supervised is $81 \mathrm{PAI}$ teachers spread over 55 junior high schools.

Follow-up evaluation is done by direct training and coaching. To improve teacher performance through training as an effort to improve teacher competence. Teacher competence is a set of knowledge, skills, and behaviors that must be possessed, internalized, and mastered by teachers in carrying out their professional duties (Rusijono, Amat Jaedun, Badrun Kartowagiran, Ahman, Lukman A. R. Laliyo, 2020). In carrying out professional duties, at least teachers have personality competence, pedagogic competence, professional competence, and social competence. (Karim et al., 2021). In addition, teachers are given motivation and a humanistic approach to be able to meet performance standards and be able to take career paths for both PNS and non-PNS teachers. One indicator of the motivation for the performance of PNS teachers is the increase in the working group and obtaining teacher certification for non-PNS teachers. Obstacles in supervision the limited number of supervisors, limited time and terrain to go to school.

Based on the results of interviews with IRE teachers who are Civil Servants (PNS) and nonPNS (honorary) IRE teachers, supervision and evaluation with a humanistic approach to PAI teachers at SMP in Pangandaran Regency is carried out with the following process:

Observation of performance through supervisory supervision which is carried out every month. the supervision method is carried out by direct supervision of the supervisor visiting the teacher at the school where they work or by means of an assessment report submitted by the teacher to the supervisor without visiting the school where they work. implementation and assessment of online learning.

Guidance, some of the shortcomings of IRE teachers found based on the results of supervision include: Incomplete learning administration, lack of discipline for IRE teachers in carrying out teaching assignments, teachers' pessimism about their future career, such as honorary teachers who consider quitting as IRE teachers because their profession does not guarantee their lives with the incentives they receive tend to be below the regional UMR standard, and civil servant teachers who don't get promoted even though they have a long working period.

To overcome teachers who have deficiencies in learning administration, supervisors provide opportunities for teachers to make improvements within the specified timeframe and followed by conducting technical guidance through personal counseling to identify the factors causing problems that occur in teachers. Training on the preparation of teaching administration and learning methods and Focus Group Discussion (FGD).

Coaching is carried out by providing guidance with individual coaching techniques and through training or workshops. Individual coaching is carried out with self-evaluation, the teacher is directed to conduct a self-evaluation of the shortcomings that must be improved and selfpotential that must be developed. Supervisors function as Advising In carrying out the supervisory function, supervisors should act as: Giving direction, assistance and guidance to teachers regarding the quality learning process/guidance to improve the quality of the process and learning outcomes/student guidance (Maranting, 2020). 
The coaching process is one of the important steps in maintaining the stability of education, so that schools are able to develop further (Puspitasari et al., 2020). Briefing is done in steps; identify the factors that cause errors made by the teacher, then directives are made to make improvements by completing directing the teacher to resolve the causes that hinder the implementation of their duties so that they are neglected. The causes found in the field that cause delays in the performance of PAI teachers include; lack of ability to use information technology tools, lack of support facilities from schools for learning administration work, low teacher incentives and lack of teacher motivation in developing careers.

Development, In the process of improving the quality of educational resources, teachers become one of the main components for continuous coaching and development, so as to improve teacher performance in schools (Ubabuddin, 2019). Teacher professional growth can be facilitated through classroom-based professional learning, and ongoing access to expert knowledge and support (Muir \& Muir, 2021). The need for future certainty is one of the motivational factors for teachers. PAI teachers are broadly divided into two groups, namely honorary teachers and PNS teachers. honorary teachers who are appointed by the organizing Foundation whose incentives are paid by the school where they work with the budget capacity of each school, where the average incentive for teachers is below the regional minimum wage every month. but besides that, honorary teachers can get incentives from the ministry of religion through teacher incentive programs or teacher certification. to honorary teachers, supervisors provide direction to take a career path until they can get teacher certification allowances. By providing relevant information related to various things that must be taken, administrative completeness that must be prepared and assisting teachers in the work process. because teachers often lose their enthusiasm due to many obstacles, such as the limited quota of teacher certification participants and the long waiting period. Based on the informant we interviewed, one of the honorary teachers said that supervision carried out coaching with a personnel approach so that each teacher proceeded to take the career path through the strategic information he conveyed.

Assessment, teacher performance reports are evaluated periodically at the end of the month, the end of the semester and the end of the year which are submitted through the academic supervision report book submitted to the Ministry of Religion office of Pangandaran Regency and the Pangandaran Regency Education Office.

Based on the results of the research data analysis, the humanistic approach in the supervision of PAI SMP teachers in Pangandaran Regency is described as follows:

Figure. 1

Humanistic Approach in Supervision and Evaluation of Islamic Religious Education

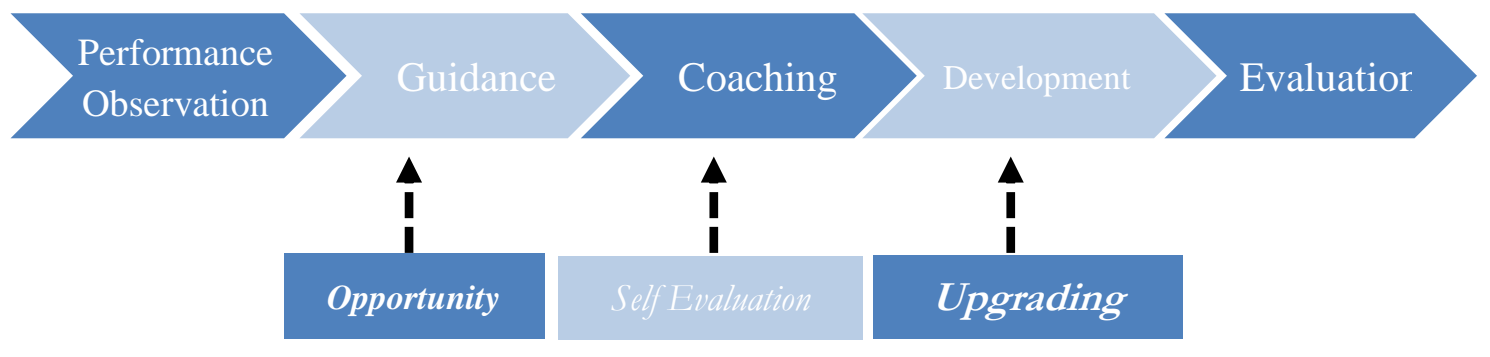




\section{CONCLUSION}

Based on the results of the analysis of this study, it was concluded that the supervision and evaluation carried out by the supervisor of IRE teachers at the Pangandaran Regency Middle School was carried out by: 1) Observing performance, through supervision which was carried out routinely every month. 2) Guidance either individually or in groups for IRE teachers who have problems. Supervisors provide technical guidance through personal counseling, training, workshops and Focus Group Discussions related to career guidance. 3) Coaching, identifying the factors that cause problems for IRE teachers in carrying out their duties and taking career paths. 4) Development, direction to make improvements by completing directing teachers to resolve the causes that hinder the implementation of their duties so that they are neglected. 5) Assessment, teacher performance reports are evaluated periodically through academic reports

The humanistic approach in supervising IRE teachers is carried out by: 1) Opportunity, namely by providing opportunities for continuous improvement by; conduct a self-evaluation of the obstacles that cause performance to decline, teaching administration is incomplete and lack of motivation in developing a career. Provide space and time to make improvements to deficiencies both administratively and in terms of performance by conducting counseling and motivation. 2) Self Evaluation, helping teachers to evaluate their potential. the ability to explore one's strengths and actualize it through the development of IRE learning, providing intensive guidance on teaching skills and learning administration even though the teacher understands it. 3) Upgrading, directing to make changes, exploring self-potential by providing understanding of the principle that everyone can do something new by learning new knowledge.

Based on the description of the research results in the humanistic approach to the supervision of IRE SMP teachers in Pangandaran Regency, there are still several obstacles, including: 1) The limited number of PAI supervisors, with the large number of IRE teachers at the junior high school level in Pangandaran Regency with a total of 81 teachers who are fostered by one supervisor. become an obstacle in optimizing the implementation of supervision. 2) Availability of facilities for upgrading IRE teachers. The implementation of seminars, workshops or other activities to improve the competence of IRE teachers still needs to be supported by strategic policies from the Ministry of Religion. 3) Limited quota for IRE teacher certification so that there are still many teachers who have been teaching for a long time but have not received professional allowances as part of paying attention to the welfare of IRE teachers.

\section{REFERENCES}

Adib, H. S., Mardapi, D., Zamroni, Z., \& Jait, A. (2019). Evaluation of Islam education teachers training implementation. Jurnal Penelitian Dan Evaluasi Pendidikan, 23(2), 106-116. https://doi.org/10.21831/pep.v23i2.20986

Badrudin. (2013). Dasar Dasar Manajemen. CV. Alfabeta.

Budiyanti, N., Aziz, A. A., \& Erihadiana, M. (2020). Strategy of Insan Kamil in Building Green Education. International Journal on Advanced Science, Education, and Religion, 3(2), 72-82. https://doi.org/10.33648/ijoaser.v3i2.54

Committe, J. (1981). Standar For Evaluation of Educational Programs, Project and Matrials. Terjemah Rasdi Ekosiswojo. IKIP Semarang Press.

Creswell. (2012). Educational Research. Pearson.

Fauzi, A. (2017). Kepemimpinan Kepala Madrasah Dalam Mengembangkan Lembaga Pendidikan 
Islam. Nidhomul Haq: Jurnal Manajemen Pendidikan Islam, 2(2), 42-53. https://doi.org/10.31538/nidhomulhaq.v2i2.31

Gusmadi, G. (2016). Pelaksanaan Manajemen Pengawasan Pendidikan Agama Islam Di Sma Negeri Di Kabupaten Tanah Datar. Al-Fikrah: Jurnal Manajemen Pendidikan, 2(2), 133. https://doi.org/10.31958/jaf.v2i2.378

Harahap, M., \& Siregar, L. M. (2017). Konsep Pendidikan Islam Dalam Membentuk Manusia Paripurna. Jurnal Pendidikan Agama Islam Al-Thariqah, 2(2), 148-163. https://doi.org/10.25299/althariqah.2017.vol2(2).1040

Jess Feist dan Gregory J. Feist. (2008). Theories of Personality (diterjemabkan oleb: Yudi Santoso). Pustaka Belajar.

Joko Budi Santoso. (2011). Peranan Pengawas Sekolah Dalam Ujian Nasional. UII Press.

Kadis. (2015). Peningkatan Kemampuan Guru Dalam Pengelolaan Pembelajaran Tematik Saintifik

Melalui Supervisi Klinis Pendekatan Humanistik Teknik Implant Bagi Guru Kelas IV Dabin

I Gugus "Sukarno-Hatta" Dinas Pendidikan Kecamatan Gabus Kabupaten Pati Pada Semester I Tahu. REFLEKSI EDUKATIKA : JURN AL ILMIAH KEPENDIDIKAN, 5(1). Karim, A., Kartiko, A., Edwar, D., Ika, D., \& Kumalasari, D. (2021). The Effect of The Supervision of The Principal and The Professional Competency of Teachers on Teacher Performance in Private MI in Pacet District. Nidhomul Haq: Jurnal Manajemen Pendidikan Islam, 497-512.

Lutfah, A., Hariyati, N., \& Handayaningrum, W. (2019). Improved Teacher Performance Through Work Culture And Environment. International Journal for Educational and Vocational Studies, 1(8), 859-863.

http://ojs.unimal.ac.id/index.php/ijevsDOI:https://doi.org/10.29103/ijevs.v1i8.2240

Maranting, H. S. (2020). Peranan Pengawas Pendidikan Agama Islam dalam Meningkatkan Kualitas Guru (Studi Kasus di Mts Al-Khairaat Kota Gorontalo). Tadbir: Jurnal Manajemen Pendidikan Islam, 8(1), 76-87. https://doi.org/10.30603/tjmpi.v8i1.1153

Miftahul Ulum. (2020). Metodologi Pengawasan Dengan Pendekatan Agama Dalam Dunia Pendidikan. Al-Insyiroh: Jurnal Studi Keislaman, 6(2), 127-143. https://doi.org/10.35309/alinsyiroh.v6i2.3836

Muir, T., \& Muir, T. (2021). Achieving Teacher Professional Growth Through Professional Experimentation and Changes in Pedagogical Practices Experimentation and Changes in Pedagogical Practices. Australian Journal of Teacher Education, 46(9).

Noer Rohmah 1. (2019). Pengawasan Pendidikan Dalam Perspektif. Jumal Pendidikan Ilmiah, 4(2), 31-53.

Prakasiwi, A.E, Suarni, K.N, Gading, K. (2013). Jurnal Bimbingan Konseling. Jurnal Bimbingan Konseling, 1(1), 100-105. https://osf.io/p56we/download

Puspitasari, F. F., Sulaiman, A., \& Supriyanto, S. (2020). the Integrated Islamic School'S Characteristics and Strategies for Human Resource Supervision. Nidhomul Haq: Jurnal Manajemen Pendidikan Islam, 5(3), 304-320. https://doi.org/10.31538/ndh.v5i3.821

Rachmahana, R. S. (2008). Psikologi Humanistik dan Aplikasinya dalam Pendidikan. El-Tarbawi, 1(1), 99-114. https://doi.org/10.20885/tarbawi.vol1.iss1.art8

Ratu, B. (2009). Bau Ratu Prodi Bimbingan Konseling, Jurusan Ilmu Pendidikan Bau Ratu , Psikologi Humanistik ( Carl Rogers) Dalam Bimbingan dan Konseling Bau Ratu, Psikologi Humanistik ( Carl Rogers) Dalam Bimbingan dan Konseling. Psikologi Humanistik (Carl 
Rogers), 1951 , $10-18$.

http://jurnal.untad.ac.id/jurnal/index.php/Kreatif/article/download/3349/2385

Rusijono, Amat Jaedun, Badrun Kartowagiran, Ahman, Lukman A. R. Laliyo, S. M. (2020). DEVELOPING THE TEACHER'S SOCIAL COMPETENCY ASSESSMENT INSTRUMENT IN THE FOURTH INDUSTRIAL REVOLUTION ERA. Jurnal Penelitian Dan Evaluasi Pendidikan, 24(02), 125-135. https://doi.org/https://doi.org/10.21831/pep.v24i2.29482

Shihab, M. Q. (2017). Pesan, Kesan dan Keserasian Al Qur'an Volume 13. PT Lentera Hati.

Stufflebeam dalam Lababa. (2008). Evaluationt and Enlighment For Decision Making. Ohio State University, Evaluation Center.

Sugiyono. (2013). Metode Penelitian Manajemen. CV. Alfabeta.

Sugiyono. (2018). Metode Penelitian Kualitatif. CV. Alfabeta.

Sutiah. (2016). Pengawasan Pendidikan Agama Islam Sebagai Quality Contrl Implementai Kurikulum Dalam Peningkatan Mutu Pendidikan di Madrasah. Nizamia Learning Center.

Ubabuddin. (2019). Pelaksanaan Supervisi Pembelajaran.

Untari, L. (2016). AN EPISTEMOLOGICAL REVIEW ON. 1, 59-72.

Usman, M. U. (2009). Menjadi Guru Profesional. PT Remaja Rosdakarya.

Zainal Arifin. (2020). Tafsir Ayat Ayat Manajemen. PT Remaja Rosdakarya. 